\title{
Ceria Zirconia Mixed Oxides Prepared by Hydrothermal Templating Method for the Oxidation of Ethyl Benzene
}

\author{
Cimi A. Daniel, S. Sugunan* \\ Department of Applied Chemistry, Cochin University of Science and Technology, \\ Cochin-682022, Kerala, India.
}

Received: 4th June 2013; Revised: 20th July 2013; Accepted: 18th August 2013

\begin{abstract}
$\mathrm{CeO}_{2}-\mathrm{ZrO}_{2}$ oxides were prepared by the surfactant-templated method using cetyl trimethyl ammonium bromide (CTAB) as template. These were characterized by XRD, FT-IR, TEM, SEM, BET and TPD-CO ${ }_{2}$. The XRD data showed that as prepared $\mathrm{CeO}_{2}-\mathrm{ZrO}_{2}$ powder particles have single phase cubic fluorite structure. HRTEM shows mesoscopic ordering. Average particle size is $12-13 \mathrm{~nm}$ as calculated from particle histogram. The nitrogen adsorption/desorption isotherm was classified to be type IV isotherm, typical of mesoporous material. The presence of uni-modal mesopores are confirmed by the pore size distribution which shows pore distribution at around $60 \AA$. The catalytic activities of the prepared material were tested in liquid phase oxidation of ethylbenzene with tert-butyl hydroperoxide (TBHP) as oxidant. Ceria zirconia catalyst modified with chromium was active for ethylbenzene conversion $(65.3 \%)$ with $77 \%$ selectivity towards acetophenone. (c) 2013 BCREC UNDIP. All rights reserved
\end{abstract}

Keywords: Mixed rare earth oxide; Ceria-zirconia; XRD; Ethylbenzene oxidation

How to Cite: Daniel, C.A., Sugunan, S. (2013). Ceria Zirconia Mixed Oxides Prepared by Hydrothermal Templating Method for the Oxidation of Ethyl Benzene. Bulletin of Chemical Reaction Engineering \& Catalysis, 8 (2): 97-104. (doi:10.9767/bcrec.8.2.5053.97-104)

Permalink/DOI: http://dx.doi.org/10.9767/bcrec.8.2.5053.97-104

\section{Introduction}

The very essential and most important use of ceria containing materials is catalytic application in automotive three-way catalysts (TWC) [1] and oxidation catalysts (for example, diesel oxidation catalysts, DOC) because of their oxygen storage capacity (OSC) based on the unique redox behavior between $\mathrm{Ce}^{3+}$ and $\mathrm{Ce}^{4+}[2,3]$.

$\mathrm{CeO}_{2}$ is included in materials used in fuel-cell processes [4], in oxygen permeation membrane sys-

* Corresponding Author.

E-mail: ssg@cusat.ac.in (S. Sugunan ) tems [5], and as catalysts in numerous economically and technologically important industrial processes. The presence of $\mathrm{CeO}_{2}$ promotes various catalytic reactions such as $\mathrm{CO}_{2}$ activation, $\mathrm{CO}$ oxidation, $\mathrm{CO} / \mathrm{NO}$ removal, low-temperature water-gas shift [6]reaction, oxidation of different hydrocarbons, wet oxidation processes of organic compounds, the removal of total organic carbon from industrial wastewaters, methane reforming with $\mathrm{CO}_{2}, \mathrm{SO}_{2}$ reduction with $\mathrm{CO}$.

The major drawback of an oxygen storage system based on pure $\mathrm{CeO}_{2}$ is related to its thermal resistance, low-temperature activity and textural stability, which are not high enough to meet the re- 
quirements of high-temperature applications. So its use is highly discouraged as pure ceria is poorly thermostable [7, 8]. Relative to pure ceria, ceriazirconia mixed oxides are known to bear a high thermal resistance and increased OSC. Incorporation of zirconium into ceria leads to structural modification of the cubic fluorite structure of ceria that result in the decrease of the cell volume and activation energy for oxide ion diffusion [8].

Effective utilization of ethylbenzene, available in the xylene stream of the petrochemical industry to more value added products is a promising one in chemical industry. The oxidation products of ethylbenzene are widely employed as intermediates in organic, steroid and resin synthesis [9-11]. Catalytic oxidation of ethylbenzene (EB) with air gives ethylbenzene hydroperoxide (EBHP). The main reaction by-products are acetophenone (AP), methyl phenyl carbinol (MPC) and phenol (PHE). Epoxidation of propylene with EBHP produces propylene oxide. MPC is later dehydrated to yield the monomer styrene [10]. Zeolite encapsulated Co (II), $\mathrm{Ni}$ (II) and $\mathrm{Cu}$ (II) complexes gave acetophenone as the only partial oxidation product during ethyl benzene oxidation with $\mathrm{H}_{2} \mathrm{O}_{2}[12,13]$. Titanosilicates mainly catalyze ring hydroxylation of arenes with $\mathrm{H}_{2} \mathrm{O}_{2}$, whereas vanadium and chromium substituted zeolites and aluminophosphate molecular sieves have been known to favour side-chain oxidation selectively [14]. Therefore, our primary main aim was to understand the path of the reaction, which occurs either by the oxidation of primary or the secondary carbon atom or by the aromatic ring hydroxylation. Furthermore, the existing industrial production of acetophenone is through the oxidation of ethyl benzene with molecular oxygen using cobalt cycloalkane carboxylate or cobalt acetate as catalyst in acetic acid solvent [15]. This method suffers from its corrosive and environmentally aloof nature. Hence it is highly desirable to develop an ecofriendly catalysts system for the oxidation of ethyl benzene selectively to acetophenone. Therefore we have attempted to utilize the mesoporous nature of ceria zirconia catalyst which is reflected in reasonable conversion of ethyl benzene and selectivity to acetophenone, the desired product. Synthesis of the catalyst was done by surfactanttemplated method and structurally characterized using different physico-chemical techniques.

\section{Materials and Methods}

\subsection{Experimental Process}

$\mathrm{Ce}\left(\mathrm{NO}_{3}\right)_{3} .6 \mathrm{H}_{2} \mathrm{O}$ and $\mathrm{ZrOCl}_{2} .8 \mathrm{H}_{2} \mathrm{O}$ were dissolved in a vessel with $500 \mathrm{ml}$ deionized water to obtain a cerium/zirconium mixed solution with a Ce/Zr mole ratio of 1:2. And then it was slowly added to a 500 $\mathrm{ml}$ solution containing cetyl trimethyl ammonium bromide (surfactant/cerium nitrate $=3.4$ molar ratio) under agitation, followed by adding $\mathrm{NH}_{4} \mathrm{OH}$ (28 wt \%) into the mixture, the $\mathrm{pH}$ of the mixture was maintained at around 11 . The gel was loaded into a stoppered Teflon bottle and heated hydrothermally at $100{ }^{\circ} \mathrm{C}$ for $48 \mathrm{~h}$. The resultant solid was recovered by filtration, washing and then it was dried in air at $80^{\circ} \mathrm{C}$ for $12 \mathrm{~h}$. Finally, the sample was calcined at $600{ }^{\circ} \mathrm{C}$ for $4 \mathrm{~h}$. It was then impregnated with an aqueous solution of chromium nitrate. The volume of the aqueous solution of metal used for impregnation depended on the amount of the support. The modified ceria-zirconia catalyst was dried at $120^{\circ} \mathrm{C}$ for $2 \mathrm{hrs}$ and then it was calcined at $400^{\circ} \mathrm{C}$ for $4 \mathrm{~h}$.

\subsection{Characterization}

Simultaneous determination of surface area, pore size distribution and total pore volume of the samples were achieved in a Micromeritics Tristar 3000 surface area and porosity analyzer. XRD analysis was carried out using Rigaku D-Max Ni filtered $\mathrm{Cu} \mathrm{K} \alpha$ radiation $\left(\lambda=1.5406 \mathrm{~A}^{0}\right)$ diffractometer equipped with diffracted beam monochromator at a scan rate of $5 \%$ min analyzer. The Infrared induced vibrations of the sample were recorded using Thermo Nicolet 380 FTIR Spectrometer by means of $\mathrm{KBr}$ pellet procedure. Transmission Electron Microscopy was carried out in ultra high resolution analytical electron microscope JEOL 3010. The sample was dispersed in ethanol through sonication and then drop casted on a carbon-coated copper grid. Scanning electron micrographs was taken using JEOL Model JSM-6390LV scanning electron microscope with a resolution of $1.38 \mathrm{eV}$. The powdered sample was dusted on a double sided carbon tape, placed on a metal stub and was coated with a layer of gold to minimize charge effects. Thermogravimetric analysis was done on a Perkin Elmer Pyris Diamond thermogravimetric analyser under nitrogen atmosphere at a heating rate of $10{ }^{\circ} \mathrm{C} / \mathrm{min}$ from room temperature to $800{ }^{\circ} \mathrm{C}$ with samples mounted on a platinum sample holder. UV-VIS DR spectra were taken in the range $200-800 \mathrm{~nm}$ on Labomed UV-VIS double beam UVD-500 spectrophotometer equipped with an integrating sphere assembly with a charged coupled device detector, using $\mathrm{BaSO}_{4}$ as reflectance standard. Temperatureprogrammed desorption study of $\mathrm{CO}_{2}$ was carried out in Micromeritics Pulse Chemisorb 2705.

\subsection{Catalytic Activity}

The liquid-phase oxidation of ethyl benzene was carried out in a $50 \mathrm{ml}$ round bottom flask. The flask was immersed in an oil bath in order to make 
the working temperature constant, which was connected with a condenser. In a typical run, catalyst and substrate were added to the solvent. The oxidant, tertiary butyl hydro peroxide (TBHP) was added to the system after attaining the reaction temperature. The reaction mixture was stirred using a magnetic stirrer. Reaction products were analyzed on Chemito 1000 GC equipped with FID detector and a BP-1 capillary column. Analysis was done using a linear temperature programme (333 to $398 \mathrm{~K}$ (ramp $283 \mathrm{~K} / \mathrm{min}$ ) and increased to $413 \mathrm{~K}$ (ramp $275 \mathrm{~K} / \mathrm{min}$ ) and finally to $475 \mathrm{~K}(-288 \mathrm{~K} / \mathrm{min}$ ) with injection and detection temperature as $523 \mathrm{~K}$. The products obtained were identified by comparison with standard ones. The catalytic activity was expressed as the percentage conversion (wt\%) of ethyl benzene and the selectivity for a product is expressed as the amount of the particular product divided by total amount of products multiplied by 100.
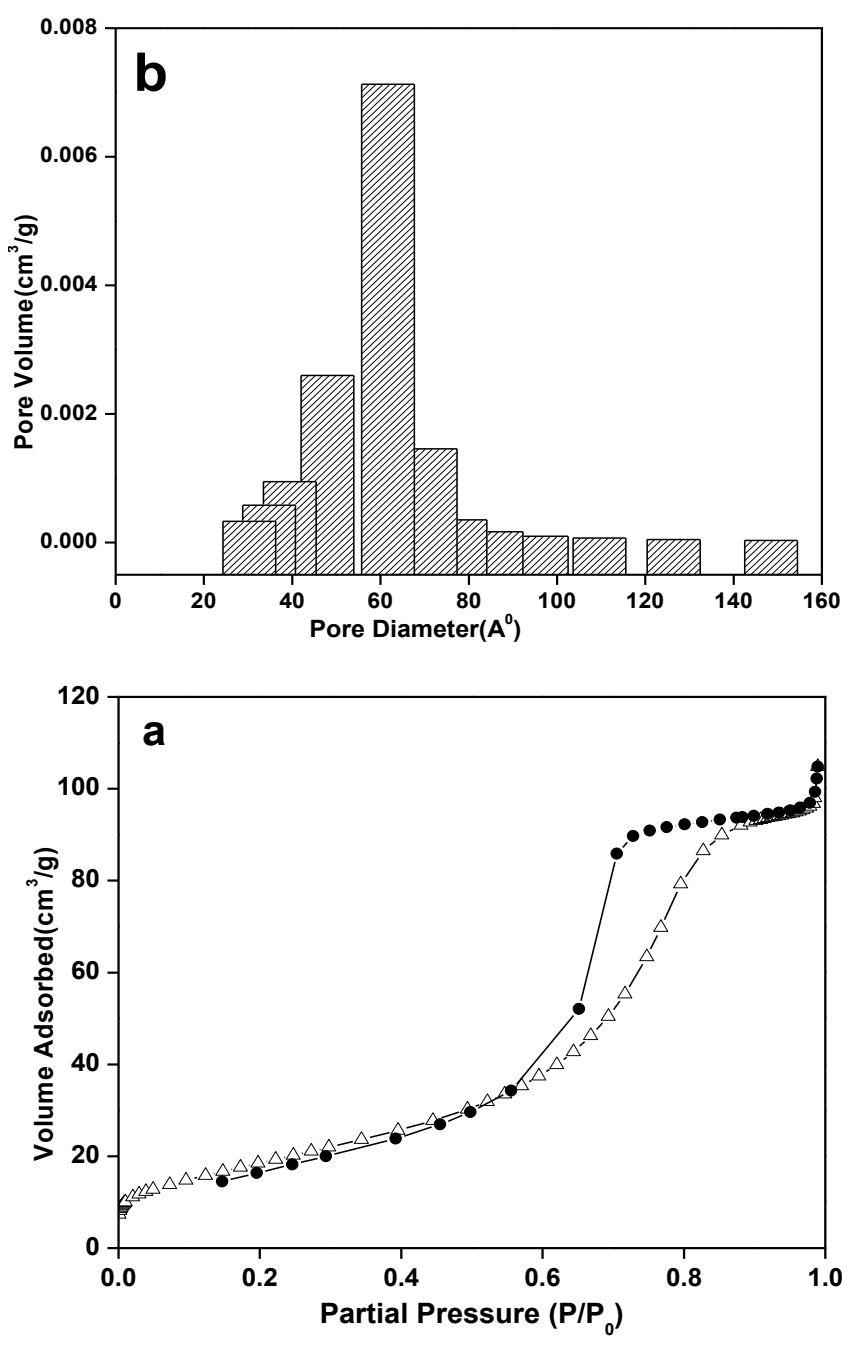

Figure 1. Nitrogen adsorption-desorption isotherm: (a) and Pore size distribution, (b) of $\mathrm{Ce}_{0.25} \mathrm{Zr}_{0.75} \mathrm{O}_{2}$

\section{Results and Discussion}

\subsection{Textural Properties: Surface Area and Pore Volume Measurements}

The most important textural parameters are calculated from nitrogen adsorption desorption isotherms: BET surface area and pore diameter. The representative isotherms of the samples are shown in Figure 1. It can be classified as a type IV isotherm, typical of mesoporous material. The shape of the curve indicates the absence of a narrow pore size distribution as suggested by the lack of the typical step in the adsorption isotherm which is observed with ordered mesoporous structure. According to IUPAC classification, the hysteresis loop is of type $\mathrm{H}_{2}$ indicating complex mesoporous structure.

The uptake at high pressure $(\mathrm{P} / \mathrm{P} 0 \sim 0.9-1.0)$ is associated with the void spaces between the particles [16]. The presence of unimodal mesopores are confirmed by the pore size distribution which shows pore distribution covering the range $30-80 \AA$ with a maximum at around $60 \AA$ for mesoporous $\mathrm{Ce}_{0.75} \mathrm{Zr}_{0.25} \mathrm{O}_{2}$ as depicted in Figure 1. The surface area, pore volume, and pore size of the support and modified catalysts are summarized in Table 1 . It is observed that the specific surface area $\left(\mathrm{S}_{\text {ВЕT) }}\right.$ and pore volume of catalyst decreased upon modification with chromium. A substantial decrease in BET surface area after impregnation is mainly due to the penetration of the dispersed chromia into the pores of the support.

\subsection{Structure and Morphology}

\subsubsection{X-ray Diffraction Analysis}

$\mathrm{X}$-ray diffraction pattern of prepared samples is displayed in Figure 2. Figure 2 shows the XRD patterns of ceria-zirconia. The ceria zirconia solid show a single phase with cubic structure, indicating that cerium and zirconium ions are uniformly distributed in the structure to form a homogeneous solid solution thereby stabilizing of fluorite structure by zirconia substitution. The peaks were ob-

\begin{tabular}{ccccc}
\hline Catalyst & $\begin{array}{c}\mathbf{S}_{\mathrm{BET}} \\
\left(\mathbf{m}^{2} \mathbf{g}^{-1}\right)\end{array}$ & $\begin{array}{c}\text { Pore } \\
\text { diameter } \\
(\mathbf{\AA})\end{array}$ & $\begin{array}{c}\text { Pore } \\
\text { volume } \\
\left(* \mathbf{1 0}^{-2}\right. \\
\left.\mathbf{c m}^{\mathbf{3}} \mathbf{g}^{-1}\right)\end{array}$ & $\begin{array}{c}\text { Crystallite } \\
\text { size }(\mathbf{n m})\end{array}$ \\
\hline $\mathrm{Ce}_{0.75} \mathrm{Zr}_{0.25} \mathrm{O}_{2}$ & 70.1 & 60.52 & 0.69 & 5.21 \\
$\mathrm{Cr} / \mathrm{Ce}_{0.75} \mathrm{Zr}_{0.25} \mathrm{O}_{2}$ & 57.9 & 60.57 & 0.27 & 4.66 \\
\hline
\end{tabular}

Table 1. Textural properties of prepared catalysts obtained from $\mathrm{N}_{2}$ sorption, ICP-AES and XRD 


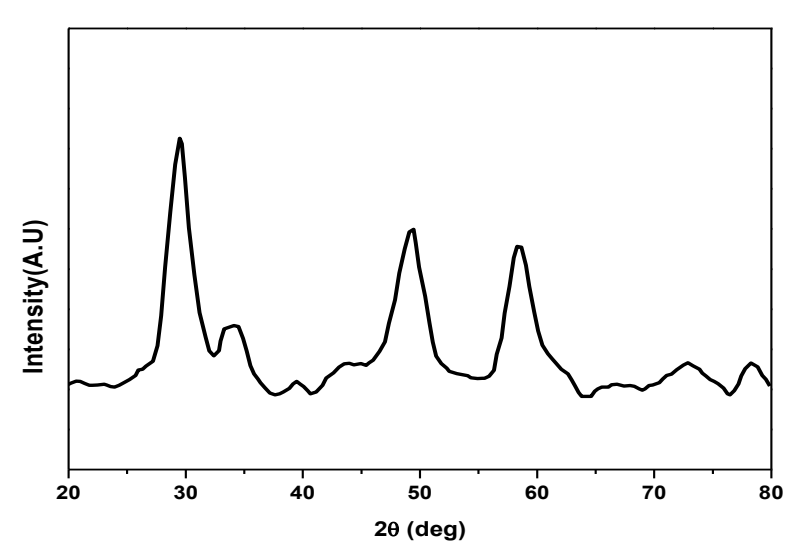

Figure 2. XRD patterns of as-prepared $\mathrm{Ce}{ }_{0.25} \mathrm{Zr}{ }_{0.75} \mathrm{O}_{2}$

served at $2 \theta \sim 29.66,34.12,49.1,58.28$ in comparison with the pure ceria peaks at $2 \theta$ values of 28.78 , $34.12,47.68$ and $56.48[17,18]$. High $2 \theta$ values in the pattern reveal the presence of a minor zirconia rich phase. Shift of peaks towards higher $2 \theta$ values is due to the small ionic radius of $\mathrm{Zr}^{4+}(0.84 \AA)$ in comparison with that of $\mathrm{Ce}^{4+}(0.97 \AA)$. The average crystallite sizes, calculated from the Scherrer equation, are shown in Table 1. Crystallite size is decreased upon modification with chromium.

\subsubsection{FT-IR Spectroscopic Analysis}

Figure 3 shows the FT-IR spectrum of $\mathrm{Ce}_{0.25} \mathrm{Zr}_{0.75} \mathrm{O}_{2}$ catalysts. Broad absorption band located in the area from 3200 to $3600 \mathrm{~cm}^{-1}$ corresponds to $\mathrm{O}-\mathrm{H}$ stretching vibration. The peaks at $1640 \mathrm{~cm}^{-1}$ corresponds to $\mathrm{H}_{2} \mathrm{O}$ bending vibration and at around $1340 \mathrm{~cm}^{-1}$ is due to $\mathrm{Ce}-\mathrm{OH}$ stretching vibration. Band in the area from $400-700 \mathrm{~cm}^{-1}$ is due to the $\mathrm{CeO}_{2}$ stretching vibration. According to literature data [19] on the vibrational active modes in the fluorite structure, absorption at around $460 \mathrm{~cm}^{-1}$ the main maximum would be assigned to the transverse mode (TO) of the triply degenerated $F_{1 u}$ fundamental, and the shoulder to the longitudinal component (LO) of the same fundamental.

\subsubsection{Transmission Electron Microscopy}

It can be seen from Figure 4 that majority of the ceria crystals consists of aggregated small crystallites of a few nanometres and very homogeneous in size. Sample shows mesoscopic ordering as observed from HRTEM. HRTEM investigation reveals the existence of several nano crystallites with well defined lattice planes. The selected area electron diffraction (Figure 4c) pattern of the sample exhibited continuous concentric rings, implying that the samples consisted of many very small

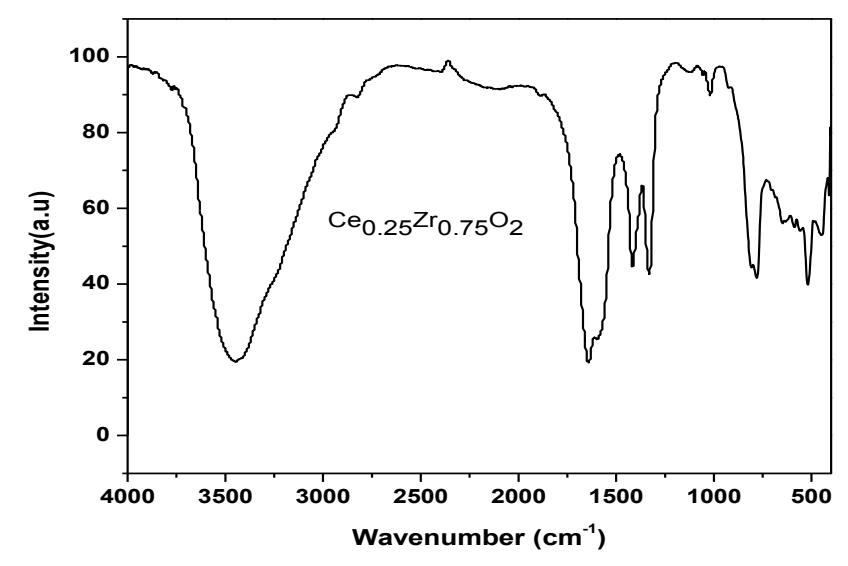

Figure 3. FT-IR spectrum of $\mathrm{Ce}{ }_{0.25} \mathrm{Zr}{ }_{0.75} \mathrm{O}_{2}$

crystallites with well-defined lattice planes. Average particle size is $12-13 \mathrm{~nm}$ as calculated from particle histogram (Figure 4d).

\subsubsection{Scanning Electron Microscopy}

Figure 5 contain electron microscopic pictures of $\mathrm{Ce}_{0.25} \mathrm{Zr}_{0.75} \mathrm{O}_{2}$ catalyst. After calcination, the particles become irregular shaped and larger sized due to the collapse in structure after heat treatment. All samples consist of crystalline aggregates with size ranging from a few to 100 micrometers

\subsubsection{Thermo Gravimetric Analysis}

Thermogram corresponding to $\mathrm{Ce}_{0.75} \mathrm{Zr}_{0.25} \mathrm{O}_{2}$ mixed oxide shows weight loss at $206{ }^{\circ} \mathrm{C}$ which is attributed to the removal of structural hydroxyl group (Figure 6). A small weight loss at $311^{\circ} \mathrm{C}$ may be due to the removal of surfactant. Weight loss at around $440{ }^{\circ} \mathrm{C}$ can be due to the transition from amorphous into crystalline form.

\subsubsection{UV-VIS Diffuse Reflectance Spectros- copy}

The spectra, in general, are broad and exhibited a myriad of poorly resolved peaks. In the case of $\mathrm{Ce}_{0.75} \mathrm{Zr}_{0.25} \mathrm{O}_{2}$, broad absorption bands are observed in the range of $200-350 \mathrm{~nm}$ (Figure 7). These bands are attributed to localized $\mathrm{O}-\mathrm{Ce}$ charge transfer transitions involving a number of surface $\mathrm{Ce}^{4+}$ ions with different coordination numbers [20]. Interband and $\mathrm{O}^{2-}-\mathrm{Zr}^{4+}$ transitions of substituted fluorite lattice [21] occur prominently around 340 $\mathrm{nm}$. Chromium modified sample also shows a broad absorption spectra is obtained. Bands at around $600 \mathrm{~nm}$ and a broad peak at around $450 \mathrm{~nm}$ are characteristic of octahedral $\mathrm{Cr}^{3+}$ in $\mathrm{Cr}_{2} \mathrm{O}_{3}$ [22]. 

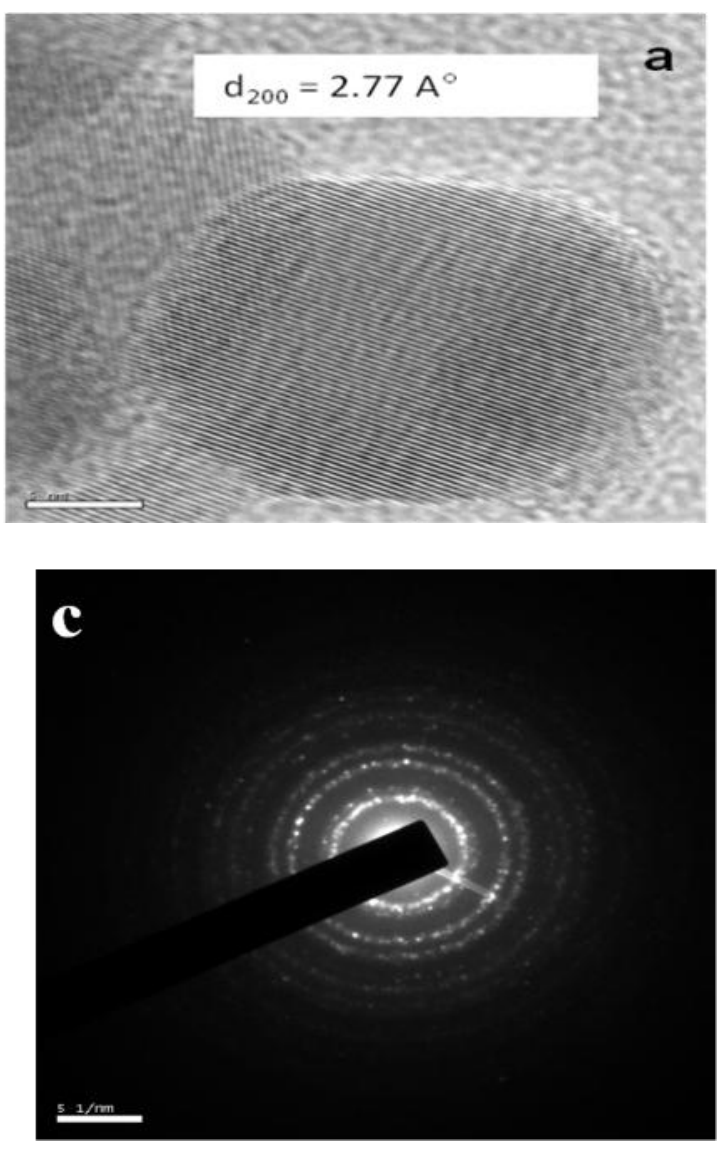

Figure 4. HR-TEM (a, b), SAED pattern (c) and particle size histogram (d) of $\mathrm{Ce}{ }_{0.25} \mathrm{Zr}_{0.75} \mathrm{O}_{2}$.

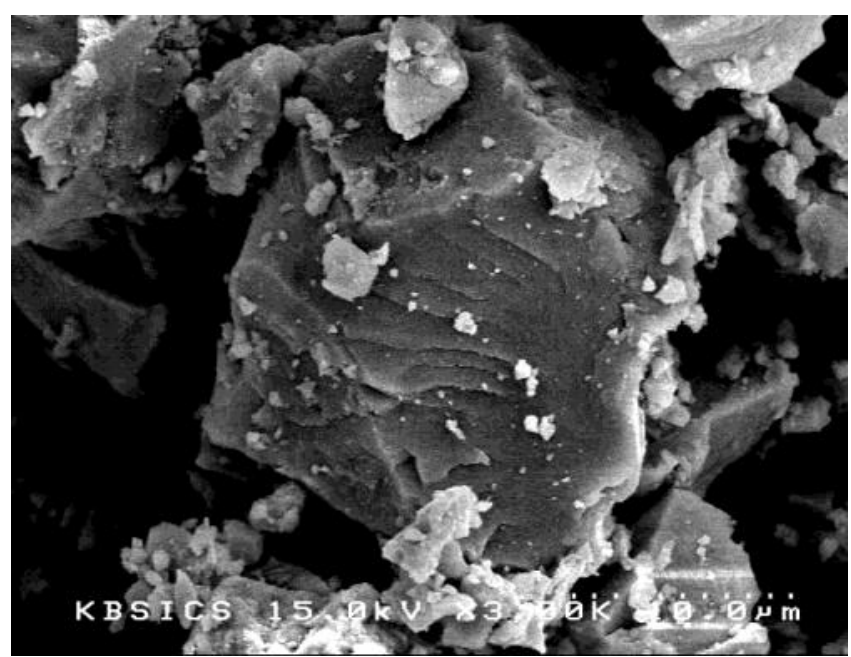

Figure 5. SEM image of $\mathrm{Ce}{ }_{0.25} \mathrm{Zr}_{0.75} \mathrm{O}_{2}$

\subsubsection{Temperature-Programmed Desorption $\left(\mathrm{CO}_{2}\right)$}

TPD spectrum of $\mathrm{CO}_{2}$ obtained after $\mathrm{CO}_{2}$ adsorption is shown in Figure 8. Two desorption peaks appear at $199^{\circ} \mathrm{C}$ and $369^{\circ} \mathrm{C}$. It is clear that there are two kinds of $\mathrm{CO}_{2}$ adsorption sites on $\mathrm{Ce}_{0.75} \mathrm{Zr}_{0.25} \mathrm{O}_{2}$ surface indicating two kinds of basic sites on the surface of the catalyst. The peak at
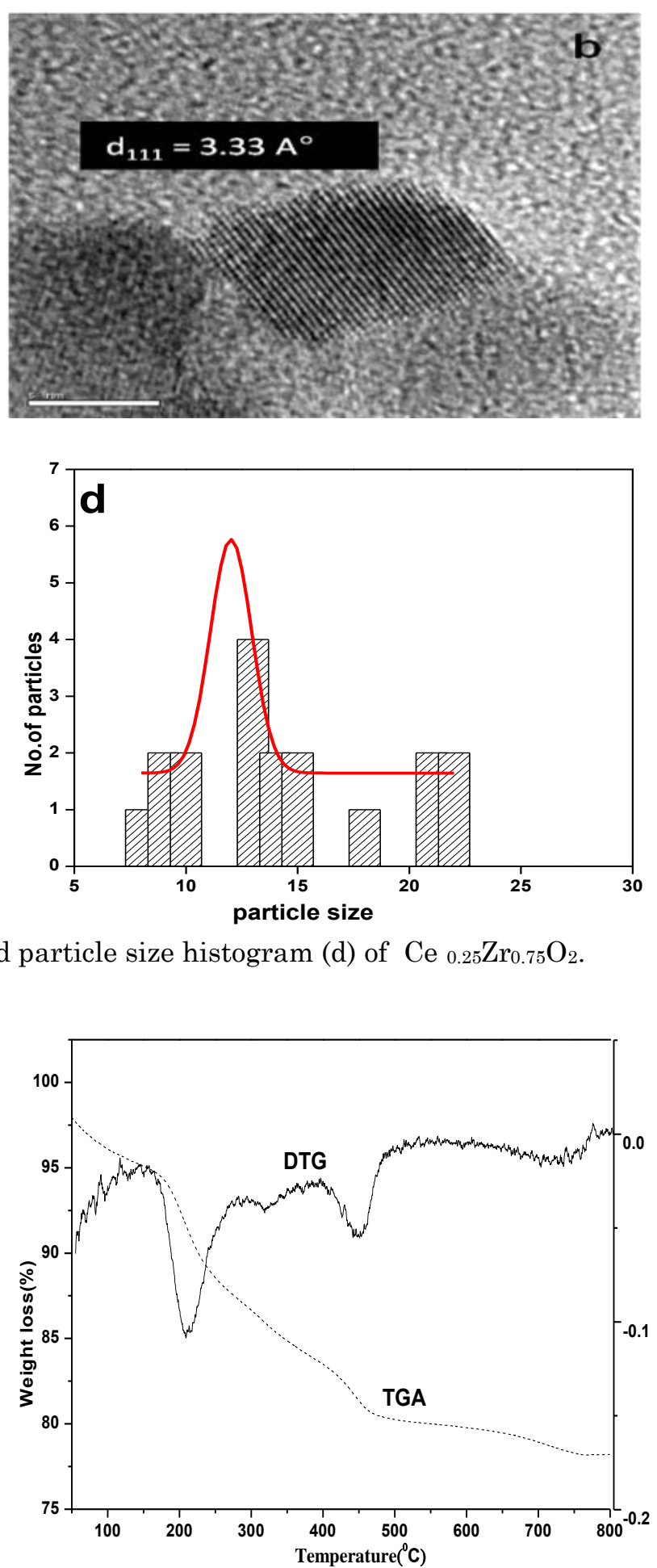

Figure 6. TG-DTA analysis of $\mathrm{Ce}_{0.25} \mathrm{Zr}_{0.75} \mathrm{O}_{2}$

lower temperature may be assigned to a monodentate carbonate interacting with $\mathrm{Ce}_{0.75} \mathrm{Zr}_{0.25} \mathrm{O}_{2}$. The desorption peak at a higher temperature may be assigned to a bidentate carbonate. The latter species being bonded to the oxide surface by two lattice oxygen ions should exhibit a higher thermal stability than the former ones $[23,24]$. 


\section{Catalytic Activity: Oxidation of Ethylben- zene}

The oxidation of ethylbenzene with t-butyl hydroperoxide over $\mathrm{Cr} / \mathrm{Ce}_{0.75} \mathrm{Zr}_{0.25} \mathrm{O}_{2}$ has been examined at various temperatures and the effect of time on ethylbenzene oxidation was studied.

$t$-Butylhydroperoxide is activated by coordinating with metal oxide. The activated distant oxygen of co-ordinated $t$-butylhydroperoxide reacts with ethylbenzene to yield the products. 1Phenylethanol from ethylbenzene is produced by insertion of oxygen between carbon hydrogen bond of the methylene group. Abstraction of an alcoholic $\mathrm{OH}$ hydrogen and the $\mathrm{CH}$ hydrogen by the activated $t$-butylhydroperoxide oxygen yields acetophenone. Formation of acetophenone requires chemi-

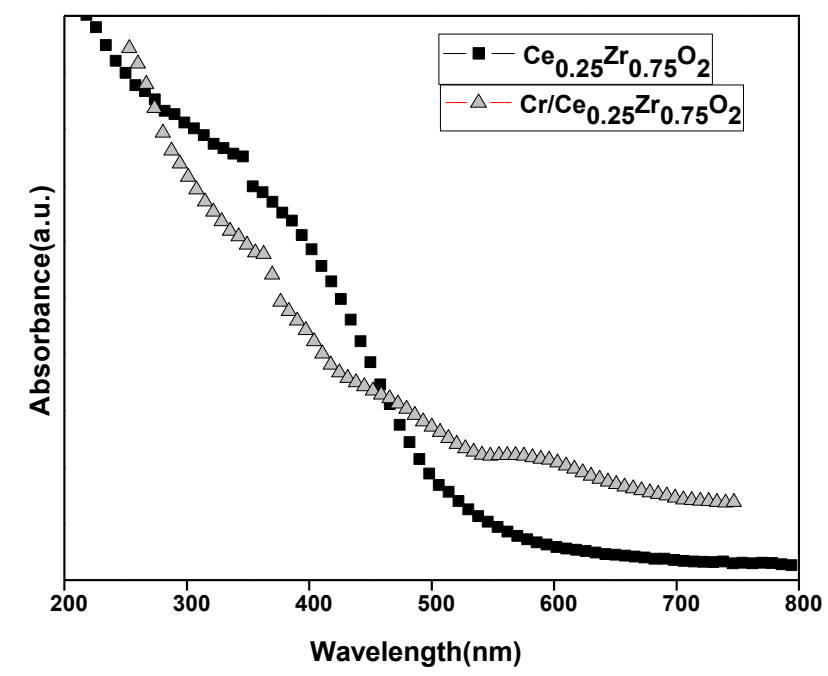

Figure 7. DR UV-vis spectra

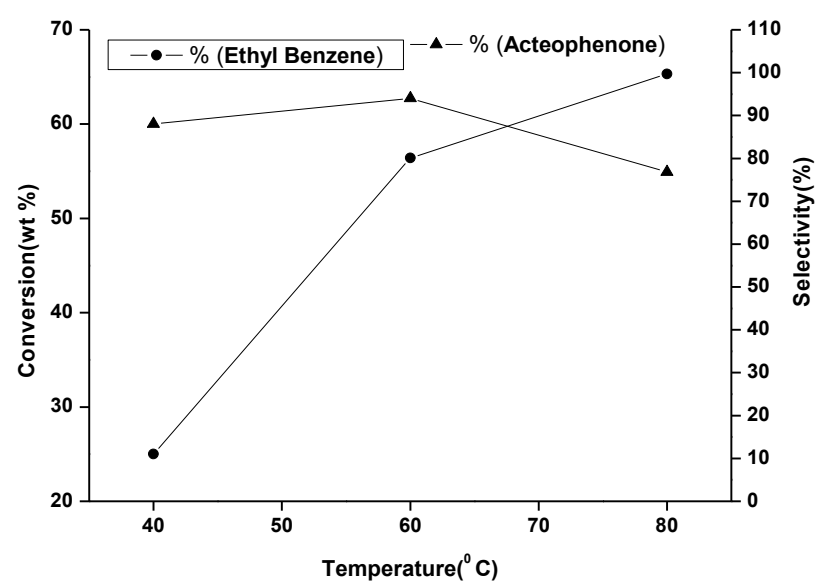

Figure 9. Effect of temperature on oxidation of ethyl benzene over $\mathrm{Cr} / \mathrm{Ce}{ }_{0.25} \mathrm{Zr}_{0.75} \mathrm{O}_{2}$. Reaction conditions: Ethyl benzene: TBHP-1:3 vol.; Acetonitrile $-10 \mathrm{ml} ; \mathrm{Cr} / \mathrm{CZ}-100 \mathrm{mg}$; Time $=6 \mathrm{~h}$ sorption of alkyl hydroperoxide on the Lewis acid sites of the catalyst. Oxidation of the secondary carbon of ethylbenzene to 1-phenylethanol, and appropriate cleavage of bonds give acetophenone [25].

As the temperature rises, there is an increase in the oxidation of substrate over the catalyst surface (Figure 9). This increase is attributed to the higher activation of TBHP. The selectivity to acetophenone increases as the temperature rises from 40 to $60{ }^{\circ} \mathrm{C}$ and decreased after $60^{\circ} \mathrm{C}$.

The effect of time on EB oxidation is illustrated in Figure 10. The reaction was carried out in presence of $\mathrm{Cr} / \mathrm{Ce}_{0.75} \mathrm{Zr}_{0.25} \mathrm{O}_{2}$ catalyst at $60{ }^{\circ} \mathrm{C}$. Ethyl benzene conversion and selectivity of AP increases almost linearly increasing with time up to $6 \mathrm{~h}$. Acetophenone was the main product with lesser con-

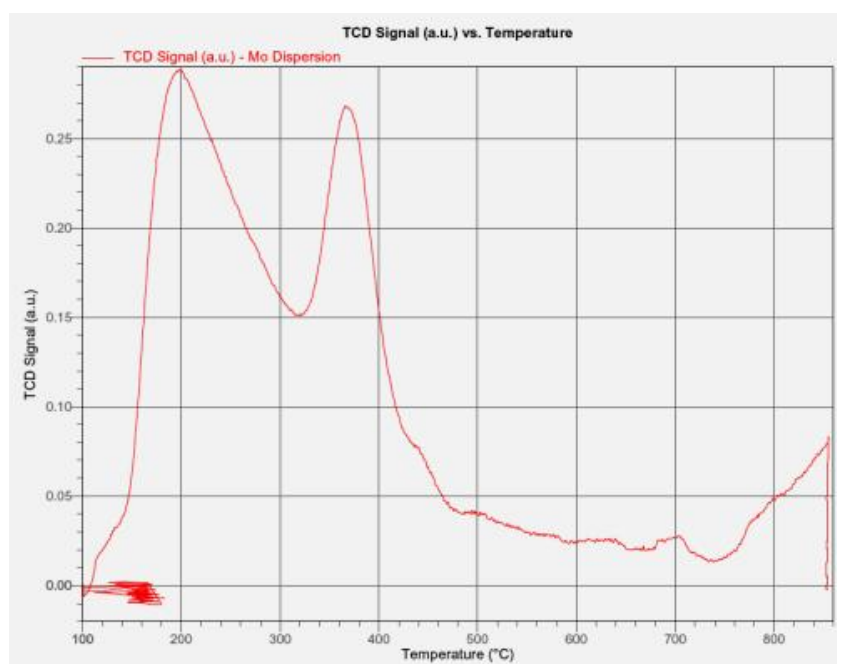

Figure 8. TPD- $\mathrm{CO}_{2}$ after $\mathrm{CO}_{2}$ adsorption on $\mathrm{Ce}_{0.25} \mathrm{Zr}_{0.75} \mathrm{O}_{2}$

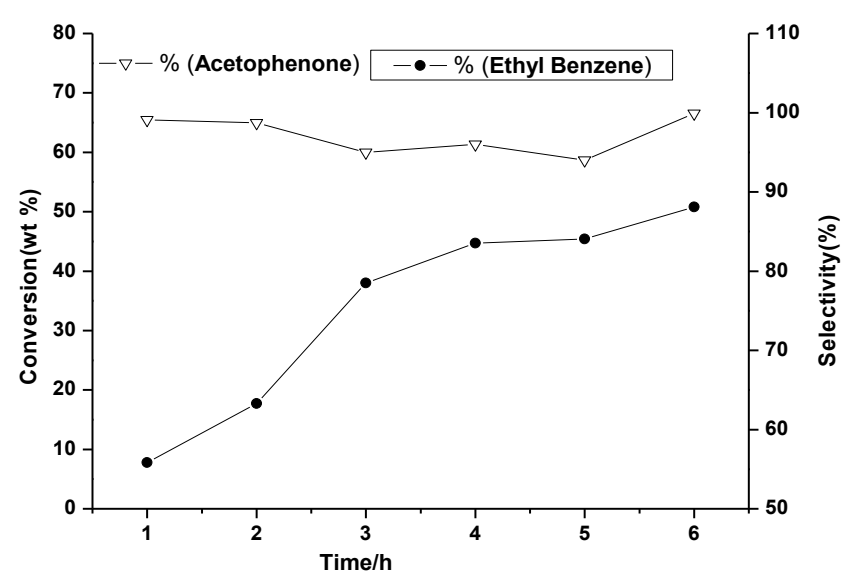

Figure 10. Effect of time on oxidation of ethylbenzene over $\mathrm{Cr} / \mathrm{Ce} \quad{ }_{0.25} \mathrm{Zr}_{0.75} \mathrm{O}_{2}$. Reaction conditions: Ethylbenzene: TBHP-1:3 vol.; Acetonitrile-10 ml; $\mathrm{Cr} / \mathrm{CZ}-100 \mathrm{mg}$; Temperature $=60{ }^{\circ} \mathrm{C}$ 


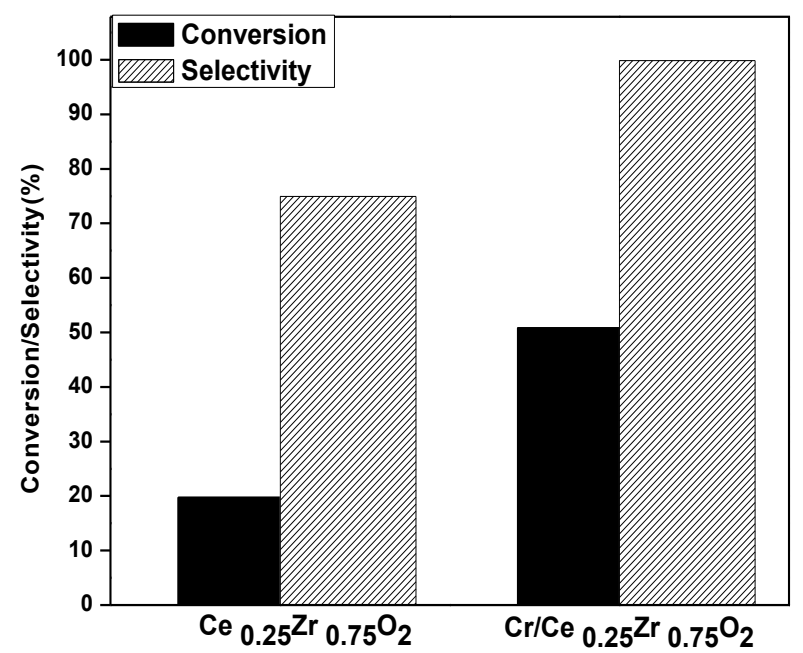

Figure 11. Comparison of catalysts on oxidation of ethylbenzene. Reaction conditions: Ethylbenzene: TBHP-1:3 vol.; Acetonitrile-10 ml; Catalyst $-100 \mathrm{mg}$; Temperature $=60{ }^{\circ} \mathrm{C}$

centration of 1-phenyl ethanol. On comparison of ceria zirconia with modified catalyst, the enhanced activity is for the chromium modified catalyst (Figure 11). The availability of chromium active sites on $\mathrm{Ce}_{0.75} \mathrm{Zr}_{0.25} \mathrm{O}_{2}$ may be accountable for the prominent increase in conversion of EB. The existence of chromium as $\mathrm{Cr}^{+3}$ as suggested from the UV DRS may act as the active site.

The EB oxidation was also carried out using hydrogen peroxide $\left(\mathrm{H}_{2} \mathrm{O}_{2}\right)$ [30 wt\%], conversion of ethylbenzene obtained was only $16 \%$ and selectivity towards acetophenone was found to be $39 \%$. It was previously reported for a ceria possessing a cubic crystal structure of the fluorite type $\left(67 \mathrm{~m}^{2} \mathrm{~g}^{-1}\right.$, $12 \mathrm{~nm}$ crystallite size), used as catalyst in the oxidation of $\mathrm{PhEt}$ with $\mathrm{H}_{2} \mathrm{O}_{2}$ and acetonitrile as solvent, that the reaction is sluggish giving $4 \%$ conversion after $6 \mathrm{~h}$, at $60{ }^{\circ} \mathrm{C}$, and benzaldehyde and acetophenone were the only products [12].

\section{Conclusions}

The nanophase of ceria-zirconia has been possible to be synthesized through a surfactant template approach. From X-ray diffraction, $\mathrm{CeO}_{2}-\mathrm{ZrO}_{2}$ powder particles have single phase cubic fluorite structure. The nitrogen adsorption/desorption isotherm can be classified as a type IV isotherm and hysteresis loop is of type $\mathrm{H}_{2}$ indicating complex mesoporous structure. Pore size distribution which shows pore distribution covering the range $30-80 \AA$ with a maximum at around $60 \AA$. HRTEM investigation reveals the existence of several nano crystallites with well defined lattice planes. Average particle size is $12-13 \mathrm{~nm}$ as calculated from particle histogram. These materials are active for ethylbenzene oxidation over TBHP as an oxidant. It was proven that ceria zirconia modified with chromium catalyst is active for ethylbenzene conversion. For a catalyst amount of $100 \mathrm{mg}$, the optimized reaction condition from our study was $\mathrm{T}=80^{\circ} \mathrm{C}, \mathrm{EB}$ to TBHP ratio of $1: 3$, and $t=6 \mathrm{~h}$.

\section{References}

[1] Jen, H.-W., Graham, G.W., Chun, W., McCabe, R.W., Cuif, J.-P., Deutsch, S.E., Touret, O. (1999). Characterization of model automotive exhaust catalysts: Pd on ceria and ceria-zirconia supports. Catalysis Today, 50: 309-328.

[2] Ozaki, T., Masui, T., Machida, K., Adachi, G., Sakata, T., Mori, H. ( 2000). Redox behavior of surface-modified $\mathrm{CeO}_{2}-\mathrm{ZrO}_{2}$ catalysts by chemical filling process. Chemistry of Materials, 12: 643649.

[3] Thammachart, M., Meeyoo, V., Risksomboon, T., Osuwan, S. (2001). Catalytic activity of $\mathrm{CeO}_{2}-$ $\mathrm{ZrO}_{2}$ mixed oxide catalysts prepared via sol-gel technique: CO oxidation. Catalysis Today, 68: 5361.

[4] Huang, J., Yang, L., Gao, R., Mao, Z., Wang, C. (2006). A high-performance ceramic fuel cell with samarium doped ceria-carbonate composite electrolyte at low temperatures. Electrochemistry Communications, 8: 785-789.

[5] Takamura, H., Ogawa, M., Suehiro, K., Takahashi, H., Okada, M. (2008). Fabrication and characteristics of planar-type methane reformer using ceria-based oxygen permeable membrane. Solid State Ionics, 179: 1354-1359.

[6] Yuana, Z.-Y., Idakiev, V., Vantomme, A., Tabakova, T., Ren, T.-Z., Su, B.-L. (2008). Mesoporous and nanostructured $\mathrm{CeO}_{2}$ as supports of nanosized gold catalysts for low-temperature watergas shift reaction. Catalysis Today, 131:203-210.

[7] Yuzhakova, T., Rakic, V., Guimon, C., Auroux, A. (2007). Preparation and Characterization of $\mathrm{Me}_{2} \mathrm{O}_{3}-\mathrm{CeO}_{2}(\mathrm{Me}=\mathrm{B}, \mathrm{Al}, \mathrm{Ga}$, In) Mixed-Oxide Catalysts. Chemistry of Materials, 19: 2970-2981.

[8] Reddy, B.M., Bharali, P., Saikia, P., Khan, A., Loridant, S., Muhler, M., Grunert, W. (2007). Hafnium Doped Ceria Nanocomposite Oxide as a Novel Redox Additive for Three-Way Catalysts. The Journal of Physical Chemistry C, 111:18781881.

[9] Tembe, G.L., Ganeshpure, P.A., Satish, S.. (1997). Oxidation of alkanes by tert-butyl hydroperoxide catalyzed by polynuclear manganese Schiff base complexes. Journal of Molecular Catalysis A: Chemical, 121:17-23. 
[10] Alcantara, R., Canoira, L., Joao, P.G., Santos, J.M., Vazquez, I. (2000). Ethylbenzene oxidation with air catalysed by bis (acetylacetonate) nickel (II) and tetra-n-butylammonium tetrafluoroborate. Applied Catalysis A: General, 203: 259-268.

[11] Mal, N.K., Ramaswamy, V., Ganapathy, S., Ramaswamy, A.V. (1995). Synthesis of tinsilicalite molecular sieves with MEL structure and their catalytic activity in oxidation reactions. Applied Catalysis A: General, 125: 233-245.

[12] Radhika, T., Sugunan, S. (2007). Vanadia supported on ceria: Characterization and activity in liquidphase oxidation of ethylbenzene. Catalysis Communications, 8: 150-156.

[13] Xavier, K.O., Chacko, J., Yusuf, K.M. ( 2004). Zeolite-encapsulated $\mathrm{Co}(\mathrm{II}), \mathrm{Ni}(\mathrm{II})$ and $\mathrm{Cu}(\mathrm{II})$ complexes as catalysts for partial oxidation of benzyl alcohol and ethylbenzene. Applied Catalysis A: General, 258: 251-259.

[14] Kumar, P., Kumar, R., Pandey, B. (1995). Oxidative organic transformations catalyzed by titanium- and vanadium-silicate molecular sieves. Synlett., 4: 289-298.

[15] Arshadi, M., Ghiaci, M., Ensafi, A.A., KarimiMaleh, H., Suib, S.L. (2011). Oxidation of ethylbenzene using some recyclable cobalt nanocatalysts: The role of linker and electrochemical study. Journal of Molecular Catalysis A: Chemical, 338: 71-83.

[16] Khan, S. (2011). Synthesis and characterization of mesoporous ceria-zirconia solid solution. M.Tech., Department of Chemical Engineering, Indian Institute of Technology, Madras.

[17] Damyanova, S., Pawelec, B., Arishtirova, K., Martinez Huerta, M.V., Fierro, J.L.G. ( 2008). Study of the surface and redox properties of ceriazirconia oxides. Applied Catalysis A: General, 337: 86-96.
[18] Damyanova, S., Perez, C.A., Schmal, M., Bueno, J.M.C. (2002). Characterization of ceria-coated alumina carrier. Applied Catalysis A: General, 234: 271-282.

[19] Lopez, E.F., Escribano, V.S., Panizza, M., Carnasciali, M.M., Busca, G. ( 2001). Vibrational and electronic spectroscopic properties of zirconia powders. Journal of Materials Chemistry, 11: 18911897.

[20] Bensalem, A., Bozon-Verduraz, F., Delamar, M., Bugli, G. (1995). Preparation and characterization of highly dispersed silica-supported ceria. Applied Catalysis A: General. 121: 81-93.

[21] Brayner, R., Ciuparu, D., da Cruz, G.M., FievetVincent, F., Bozon-Verduraz, F. (2000). Preparation and characterization of high surface area niobia, ceria-niobia and ceria-zirconia. Catalysis Today, 57: 261-266.

[22] Huiyun, L., Yinghong, Y., Changxi, M., Zaiku, X., Weiming, H., Zi, G. (2006). Preparation of highly active $\mathrm{Cr}_{2} \mathrm{O}_{3}-\mathrm{SiO}_{2}$ catalyst by sol-gel method for ethylbenzene dehydrogenation in the presence of $\mathrm{CO}_{2}$. Chinese Journal of Catalysis, 27: 4-6.

[23] Tejuca, L.G., Bell, A.T., Fierro, J.L.G., Tascon, J.M.D. (1987). Temperature-programmed desorption study of the interactions of $\mathrm{H}_{2}, \mathrm{CO}$ and $\mathrm{CO}_{2}$ with $\mathrm{LaMnO}_{3}$. Journal of the Chemical Society, Faraday Transactions 1, 83: 3149-3159.

[24] Udovic, T.J., Dumesic, J.A. (1984). Adsorptive properties of magnetite surfaces as studied by temperature-programmed desorption: Studies of $\mathrm{O}_{2}, \mathrm{NO}, \mathrm{CO}_{2}$, and $\mathrm{CO}$ adsorption. Journal of $\mathrm{Ca}$ talysis, 89: 314-326.

[25] Vetrivel, S., Pandurangan, A. (2004). Side-chain oxidation of ethylbenzene with tert butylhydroperoxide over mesoporous Mn-MCM-41 molecular sieves. Journal of Molecular Catalysis A: Chemical, 217: 165-174. 